\title{
Recent advances in the molecular pathology, cell biology and genetics of ciliopathies
}

\author{
M Adams, ${ }^{1}$ U M Smith, ${ }^{2}$ C V Logan, ${ }^{1}$ C A Johnson ${ }^{1}$
}

${ }^{1}$ Section of Opthalmology \& Neurosciences, Leeds Institute of Molecular Medicine,

University of Leeds, Leeds, UK;

${ }^{2}$ Section of Medical and Molecular Genetics, University of Birmingham Medical School, Edgbaston, Birmingham, UK

Correspondence to:

Dr C A Johnson, Section of

Opthalmology \& Neurosciences,

Wellcome Trust Brenner

Building, Leeds Institute of

Molecular Medicine, St. James's

University Hospital, Beckett

Street, Leeds, LS9 7TF, UK;

c.johnson@leeds.ac.uk

Received 28 September 2007 Revised 18 December 2007 Accepted 20 December 2007 Published Online First

3 January 2008

\begin{abstract}
Primary cilia have a broad tissue distribution and are present on most cell types in the human body. Until recently, they were considered to be redundant organelles, but progress over the past 5 years has led to an understanding of their role in normal mammalian development. The class of inherited disorders that involve aberrant ciliary function are known as ciliopathies, and although their range of severity can vary, they share some common and unexpected clinical phenotypes. The aim of this review is to assess recent insights into the structure, function and formation of primary cilia, and relate this to the pathology, molecular genetics and cell biology of the ciliopathies.
\end{abstract}

The name "cilia" derives from the Latin for "eyelash". Zimmermann is reported as the first person to observe cilia and, in the 19th century, was the first to describe the primary cilium. ${ }^{1}$ Cilia can be subdivided based on both their function and structure as either motile cilia/flagella or primary cilia. Both subtypes consist of a basal body located below the cell surface, and an axoneme that extends away from the cell. The basal body is analogous to the centrioles (a radial array of nine triplet microtubules) of the centrosome, and forms when the centrosome docks at the apical surface of the cell. The structure of the axoneme determines the subtype of cilium: in motile cilia and flagella the axoneme has a 9+2 arrangement of microtubules, whereas primary cilia have a 9+0 arrangement and are immotile (reviewed in Dawe et al). Primary cilia have a broad tissue distribution and, until recently, many scientists considered them to be redundant organelles. However, over the past 5 years, progress has been made in understanding the role of these organelles in normal mammalian development. Key to this has been the positional cloning of genes that encode structural or functional components of primary cilia, in some instances from rat or mouse models of polycystic kidney disease (PKD), bioinformatic and phylogenetic analysis of known or inferred ciliary genes, and the characterisation of ciliary proteomes. ${ }^{3-6}$

Mutations in ciliary genes give rise to a multitude of human monogenic disorders that are now collectively known as "ciliopathies" (reviewed in Badano et $a l^{7}$ ), but that often share common phenotypic features. Primary cilia are now acknowledged as vital cellular components, with probable functions as chemosensors or mechanosensors of the extracellular environment. The focus of this review will therefore be a concise overview of recent progress in the molecular genetics of ciliopathies, and a discussion of the possible functions of ciliary proteins in the context of molecular pathology and cell biology. As many of the recent advances have concerned pleiotropic conditions with an underlying primary cilium/ basal body dysfunction, we will not deal with disorders of motile cilia, such as primary ciliary dyskinesis, or ciliary disorders associated with a situs defect. The pre-eminent example of the latter is Kartagener syndrome, which arises from dysfunctional nodal cilia (a specialised form of motile primary cilia that localise at the embryonic node to establish asymmetries along the left-right axis). Further details of the molecular genetics and aetiology of these disorders are described in a number of excellent recent reviews ${ }^{89}$ and the references cited within them.

\section{CILIOPATHY PHENOTYPES}

Ciliopathies have a broad range of phenotypes encompassing a number of different autosomal recessive and dominant syndromes of previously unknown aetiology. In a previous review for the Journal of Medical Genetics, we described the common clinical features in the so-called "congenital hepatorenal fibrocystic" spectrum of phenotypes, with cystic dysplasia of the kidneys as being common feature for most conditions. ${ }^{10}$ At the time, we suggested that these phenotypic similarities arose from a common molecular pathogenesis, and 5 years on, this prediction has been proven to be largely correct. Many of the recently identified ciliary genes (table 1) encode either structural or functional components of primary cilia or basal bodies. Although the functional role of many of the encoded proteins still remains an active area of research, it is clear that the clinical aspects of many of the ciliopathy phenotypes can be explained by a ciliary defect.

Ciliated cells are usually a highly specialised, post-mitotic cell type, and are therefore nonproliferating, differentiated cells. However, cilia can also form on quiescent cells, which may undergo later rounds of cell division, and on proliferating cells. Almost all epithelial cells are ciliated, and they commonly exist as a sheet of polarised cells forming a tube or tubule with the cilia projecting into the lumen. The cilia are then exposed to the contents of the lumen where they can provide a sensory role mediating specific signalling cues, including soluble factors in the external cell environment, a secretory role in which a soluble protein is released to have an effect downstream of the fluid flow, and mediation of fluid flow if the cilia are motile. ${ }^{11}{ }^{12}$ The cell biology of the ciliopathies can be considered in terms of functional loss or complete absence of a particular 
Table 1 A summary of the ciliopathies for each inherited disorder

\begin{tabular}{|c|c|c|c|c|c|c|c|}
\hline $\begin{array}{l}\text { Inherited } \\
\text { disorder }\end{array}$ & Loci & Gene(s) & Location & $\begin{array}{l}\text { Protein } \\
\text { product }\end{array}$ & Function and other comments & Interactors & References \\
\hline \multicolumn{8}{|l|}{$\begin{array}{l}\text { PKD (autosomal } \\
\text { dominant) }\end{array}$} \\
\hline Adult type 1 & PKD1 & PKD1 & $16 p 13.3$ & PC1 & $\begin{array}{l}\text { Cell-cell or cell-matrix interactions; interacts } \\
\text { with PC-2 to produce calcium-permeable } \\
\text { nonselective cation currents }\end{array}$ & PC-2 & \\
\hline \multirow[t]{2}{*}{ Adult type 2} & PKD2 & PKD2 & $4 q 22.1$ & PC2 & Probable channel protein; interacts with PC-1 & PC-1 & \\
\hline & PKD3? & & & & $\begin{array}{l}\text { Further genetic heterogeneity suggested but not } \\
\text { proved }\end{array}$ & & \\
\hline \multicolumn{8}{|l|}{$\begin{array}{l}\text { PKHD (autosomal } \\
\text { recessive) }\end{array}$} \\
\hline Infantile type & PKHD1 & PKHD1 & $6 \mathrm{p} 12.2$ & $\begin{array}{l}\text { Fibrocystin, } \\
\text { polyductin }\end{array}$ & $\begin{array}{l}\text { Probable receptor protein that acts in collecting } \\
\text { duct and biliary differentiation; colocalises with } \\
\text { PC-2 at the basal bodies of primary cilia }\end{array}$ & & \\
\hline \multicolumn{8}{|c|}{ 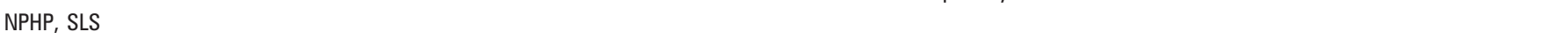 } \\
\hline Juvenile, type 1 & $\begin{array}{l}\text { NPHP1, } \\
\text { SLSN1, } \\
\text { JBTS4 }\end{array}$ & NPHP1 & $2 q 13$ & Nephrocystin & $\begin{array}{l}\text { Adaptor protein; associates with signalling } \\
\text { molecules involved in cell adhesion and actin } \\
\text { cytoskeleton organisation, and with } \beta \text {-tubulin, a } \\
\text { major component of primary cilia }\end{array}$ & $\begin{array}{l}\text { Nephrocystin-4, p130Cas/BCAR1, } \\
\text { signal-rich PTK2B, TNS, } \beta \text {-tubulin }\end{array}$ & 47,95 \\
\hline Infantile, type 2 & NPHP2 & INVS & $9 q 31.1$ & Inversin & $\begin{array}{l}\text { Primary cilia function and involvement in the cell } \\
\text { cycle; possible molecular switch between } \\
\text { different Wnt signalling cascades; left-right axis } \\
\text { determination }\end{array}$ & Nephrocystin, APC2 & $95-97$ \\
\hline Adolescent, type 3 & $\begin{array}{l}\text { NPHP3, } \\
\text { SLSN3 }\end{array}$ & NPHP3 & $3 q 22.1$ & Nephrocystin-3 & $\begin{array}{l}\text { With nephrocystin and nephrocytin-4, may } \\
\text { mediate a common developmental pathway in } \\
\text { the primary cilia of renal epithelial cells }\end{array}$ & Nephrocystin & 98 \\
\hline \multirow[t]{2}{*}{ Juvenile, type 4} & $\begin{array}{l}\text { NPHP4, } \\
\text { SLSN4, } \\
\text { JBTS4 }\end{array}$ & NPHP4 & $1 \mathrm{p} 36$ & $\begin{array}{l}\text { Nephrocystin-4, } \\
\text { nephroretinin }\end{array}$ & $\begin{array}{l}\text { Possible roles in signal transduction, cell-cell } \\
\text { adhesion and actin cytoskeleton organisation } \\
\text { and biogenesis; mutations in RPGRIP1 } \\
\text { (associated with Leber congenital amaurosis } \\
\text { type 6) disrupt the interaction with nephrocystin- } \\
4\end{array}$ & Nephrocystin, RPGRIP1 & $47,64,95$ \\
\hline & SLSN5 & IOCB1 & $3 q 21.1$ & $\begin{array}{l}\text { IOCB1, } \\
\text { nephrocystin-5 }\end{array}$ & $\begin{array}{l}\text { IOCB1 and RPGR may participate in a common } \\
\text { pathway in connecting cilia of photoreceptors } \\
\text { and to primary cilia of renal epithelial cells }\end{array}$ & RPGR, calmodulin & 95 \\
\hline $\begin{array}{l}\text { JBTS and related } \\
\text { disorders/SLS } \\
\text { phenotypes }\end{array}$ & $\begin{array}{l}\text { NPHP6, } \\
\text { SLSN6, } \\
\text { JBTS5, } \\
\text { LCA10, } \\
\text { MKS4 }\end{array}$ & $\begin{array}{l}\text { CEP290, } \\
\text { NPHP6 }\end{array}$ & $12 q 21.3$ & CEP290 & $\begin{array}{l}\text { Localised at the nuclei of renal epithelial cells in } \\
\text { a cell cycle-dependent manner, in connecting } \\
\text { cilia of photoreceptors, centrosomes and } \\
\text { primary cilia; modulates the activity of ATF4, a } \\
\text { transcription factor implicated in cAMP- } \\
\text { dependent renal cyst formation }\end{array}$ & ATF4 & $34-38$ \\
\hline \multicolumn{8}{|l|}{ MKS } \\
\hline & MKS1 & $\begin{array}{l}\text { MKS1, } \\
\text { FLJ20345 }\end{array}$ & $17 q 22$ & MKS1 & $\begin{array}{l}\text { MKS1 is a member of the flagellar apparatus } \\
\text { basal body proteome; contains a B9 domain of } \\
\text { unknown function; localises to basal bodies and } \\
\text { centrosomes, but interacts with meckelin }\end{array}$ & Meckelin & 14,15 \\
\hline & MKS2 & & $11 q 13$ & & Causative gene has not been identified & & 99 \\
\hline & $\begin{array}{l}\text { MKS3, } \\
\text { JBTS6 }\end{array}$ & $\begin{array}{l}\text { MKS3, } \\
\text { TMEM67 }\end{array}$ & $8 q 22.1$ & Meckelin & $\begin{array}{l}\text { Meckelin localises to the cell surface and } \\
\text { primary cilia; putative transmembrane receptor } \\
\text { with an extracellular cysteine-rich domain that } \\
\text { may have similarities to those in Frizzled-type } \\
\text { receptors }\end{array}$ & MKS1 & $14,36,40$ \\
\hline $\begin{array}{l}\text { Meckel-like cerebro- } \\
\text { reno-digital syndrome }\end{array}$ & $\begin{array}{l}\text { MKS4, } \\
\text { JBTS5 }\end{array}$ & $\begin{array}{l}\text { CEP290, } \\
\text { NPHP6 }\end{array}$ & $12 q 21.3$ & CEP290 & $\begin{array}{l}\text { See entry above for CEP290; mutations also } \\
\text { cause cerebro-reno-digital syndrome, with a } \\
\text { phenotype between that of MKS and JBTS }\end{array}$ & & 36 \\
\hline CORS, JPTS type B & $\begin{array}{l}\text { MKS5, } \\
\text { JBTS7, } \\
\text { CORS3 }\end{array}$ & $\begin{array}{l}\text { RPGRIP1L, } \\
\text { KIAA1005 }\end{array}$ & $16 q 12.2$ & RPGRIP1L & $\begin{array}{l}\text { Colocalises at the basal body and centrosomes } \\
\text { with CEP290, and interacts with nephrocystin-4; } \\
\text { in mice, Ftm/Rpgrip11 is necessary for the } \\
\text { establishment of left-right asymmetry and } \\
\text { patterning of the neural tube and the limbs; may } \\
\text { mediate cilium-related Shh signalling }\end{array}$ & Nephrocystin-4 & $39,63,100$ \\
\hline \multicolumn{8}{|l|}{ JPTS, CORS } \\
\hline CORS type 1 & $\begin{array}{l}\text { JBTS1, } \\
\text { CORS1 }\end{array}$ & & $9 q 34.3$ & & Causative gene has not been identified & & 28,29 \\
\hline \multirow[t]{3}{*}{ CORS type 2} & $\begin{array}{l}\text { JBTS2, } \\
\text { CORS2 }\end{array}$ & & $\begin{array}{l}11 \mathrm{p} 12- \\
\mathrm{q} 13.3\end{array}$ & & Causative gene has not been identified & & $29-31$ \\
\hline & JBTS3 & AHI1 & $6 q 23.3$ & $\begin{array}{l}\text { AAHI1 protein } \\
\text { homologue, } \\
\text { jouberin }\end{array}$ & $\begin{array}{l}\text { Unknown function; AHI1 expression may } \\
\text { contribute to the development of specific types } \\
\text { of human leukaemia; may be associated with } \\
\text { susceptibility to schizophrenia }\end{array}$ & & 32,101 \\
\hline & JBTS4 & NPHP1 & $2 q 13$ & Nephrocystin & See entry above for NPHP1; deletions of the & & 33 \\
\hline
\end{tabular}


Table 1 Continued

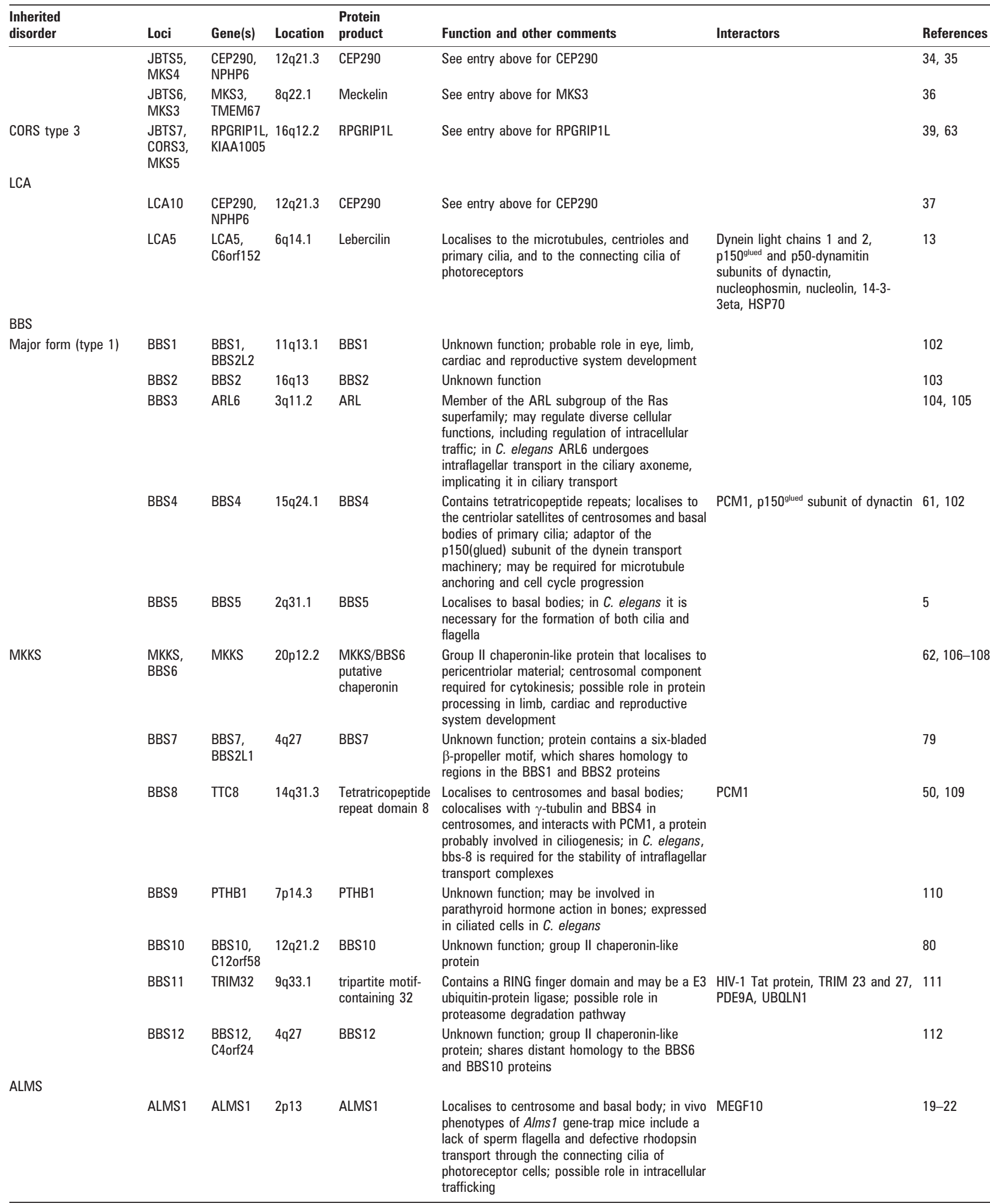


Table 1 Continued

\begin{tabular}{lllllll}
\hline $\begin{array}{l}\text { Inherited } \\
\text { disorder }\end{array}$ & Loci & Gene(s) & Location & $\begin{array}{l}\text { Protein } \\
\text { product }\end{array}$ & Function and other comments & Interactors \\
\hline $\begin{array}{l}\text { OFD syndrome } \\
\text { OFD type 1 }\end{array}$ & OFD1 & $\begin{array}{l}\text { OFD1, } \\
\text { CXorf5 }\end{array}$ & Xp22.2 & OFD1 & $\begin{array}{l}\text { Localises to centrosomes and basal bodies; } \\
\text { defective primary ciliary and left-right } \\
\text { asymmetry in Ofd1 knock-out mice, with } \\
\text { impaired patterning of the neural tube and } \\
\text { altered expression }\end{array}$ \\
ATD, Jeune syndrome & ATD1 & $\begin{array}{l}\text { IFT80, } \\
\text { WDR56 }\end{array}$ & $3 q 26.1$ & IFT80 & $\begin{array}{l}\text { Localises to the basal body and the ciliary } \\
\text { axoneme; possible role in Shh signalling }\end{array}$ & $\begin{array}{l}\text { In Chlamydomonas reinhardtii, } \\
\text { components of IFT complex B }\end{array}$
\end{tabular}

\begin{abstract}
AHI1, Abelson helper integration site 1; ALMS, Alström syndrome; APC2, anaphase-promoting complex subunit-2; ARL-6, ADP-ribosylation factor-like 6; ATD, asphyxiating thoracic dystrophy; ATF4, activating transcription factor 4; BBS, Bardet-Biedl syndrome; C. elegans, Caenorhabdits elegans; CEP290, Centrosomal protein 290 kDa; CORS, cerebello-oculorenal syndrome; GTP, guanidine triphosphate; HIV, human immunodeficiency virus; HSP, heat shock protein; IFT80, Intraflagellar transport $80 \mathrm{kDa}$ protein homologue; IQCB1, IO motif-containing protein B1; JBTS, Joubert syndrome; LCA, Leber congenital amaurosis; MEGF-10 multiple epidermal growth factor-like-domains 10; MKKS, McKusick-Kaufman syndrome; MKS, Meckel-Gruber syndrome; NPHP, nephronophthisis; OFD, orofaciodigital; PC, polycystin; PCM1, Pericentriolar material 1; PDE9A, phosphodiesterase 9A; PKD, polycystic kidney disease; PKHD, polycystic kidney and hepatic disease; PTHB1, Parathyroid hormone-responsive B1; PTK2B, protein tyrosine kinase 2B; Ref., reference; RPGR, retinitis pigmentosa GTPase regulator; RPGRIP1, retinitis pigmentosa GTPase regulator-interacting protein; SLS, Senior-Løken syndrome; TNS, tensin; TRIM, tripartite motifcontaining; UBOLN1, ubiquilin 1.
\end{abstract}

protein. For example, the outer segments of retinal rod cells are modified primary cilia, and compromised protein transport across the photoreceptor-connecting cilium causes either retinitis pigmentosa or blindness due to retinal degeneration (retinal dystrophy). Alternatively, a failure of mechanosensation in the primary cilia of renal tubular cells causes PKD. ${ }^{11} 13$

Many ciliary proteins are components of large, multi-subunit complexes, and individual proteins interact directly or indirectly within the complex. The absence or dysfunction of one component affects the function of the whole, to a greater or lesser extent, resulting in a range of phenotypic severity. Furthermore, many ciliary proteins also exist at sites other than the cilium or basal body, which implies that they may have other roles elsewhere in the cell. A second explanation could be that these proteins are produced as inactive precursors before either the formation of cilia or transport to the mature cilium.

Ciliopathies can be classified according to whether there is aberrant function in an intact cilium or complete absence/ partial loss of the mature cilium. The latter is the case with the more severe multiorgan phenotypes such as Meckel-Gruber syndrome $(\mathrm{MKS})$, but a more specific defect occurring in intact cilia is seen in the late-onset cystic kidney diseases. ${ }^{14-16}$ Alternatively, more specific defects may be due to loss of a protein or protein isoform with a highly specialised role exclusive to the eye or kidney, and both retinal degeneration and PKD are common clinical features associated with ciliopathies. Other less common features include anosmia, ataxia, liver fibrosis, cardiac defects, infertility, obesity, central nervous system (CNS) abnormalities and skeletal dysplasia. These additional features are indicative of the diverse functional roles of primary cilia during the development of the many tissues affected by the phenotypes. ${ }^{17}$ The aetiology of anosmia, for example, can be explained as an occasional manifestation of ciliopathies, because the odour receptors of the olfactory epithelium are positioned on the cilia of olfactory neurons. ${ }^{18}$

Two diseases that are known to be caused by proteins associated with primary cilia are Alström syndrome (ALMS) and orofaciodigital syndrome type 1 , and we discuss these briefly as representative examples of the ciliopathy phenotype. ALMS is an autosomal recessive disorder characterised by childhood obesity associated with type 2 diabetes mellitus, chronic hyperglycaemia, cone-rod retinal dystrophy and neurosensory deficits. The single causative gene on chromosome $2 \mathrm{p} 13$, ALMS1, encodes a novel protein that contains coiled-coil domains and a putative nuclear localisation signal. ${ }^{19} 20$ ALMS1 is widely expressed, and localises to centrosomes and basal bodies of primary cilia. ${ }^{21}$ However, the disruption of the gene in either a patient with ALMS or a gene-trap Alms1 mutant mouse strain results in normal primary cilia and microtubule cytoskeleton formation, suggesting that the ALMS phenotype results from impaired function rather than abnormal development or absence of these organelles. ${ }^{21}{ }^{22}$ These data support the findings for Bardet-Biedl syndrome (BBS; see below), indicating a unifying pathway involving primary cilia that underlies these overlapping disorders. Recent work, using small interfering RNA-mediated loss of Alms1 expression has shown that this gene is required for ciliogenesis in a ciliated cell line (mouse IMCD3 cells). Furthermore, in support of the putative functional roles of the polycystins (see below), loss of Alms1 expression prevented flow-induced $\mathrm{Ca}^{2+}$ influx into the cytosol of individual cells, thus implicating the ALMS1 protein in mechanosensation. ${ }^{23}$

Oro-facial-digital type 1 (OFD1) syndrome is an X-linked dominant condition with lethality in males. It is characterised by malformations of the face, oral cavity and digits, but is also associated with malformation of the brain and polycystic kidneys. The underlying gene, OFD1, on chromosome Xp22, encodes a protein containing coiled-coil $\alpha$-helical domains and an N-terminal Lis homology (LisH) motif. ${ }^{24}$ OFD1 is a core component of the human centrosome, and the coiled-coil domains are crucial for localising the protein to the centrosome. Importantly, most reported OFD1 mutations are predicted to cause protein truncation with loss of coiled-coil domains, presumably leading to loss of centrosomal localisation. OFD1 also localises to the basal bodies of renal epithelial cells. $^{25}$

\section{A PHENOTYPIC SPECTRUM OF DISEASE SEVERITY: JOUBERT SYNDROME AND MECKEL-GRUBER SYNDROME}

Joubert syndrome (JBTS) is a ciliopathy with extensive genetic heterogeneity and variability in phenotypic severity. It was first described in 1969 in a family containing four siblings with ataxia, mental retardation, oculomotor apraxia, hypotonia and neonatal breathing dysfunction. ${ }^{26}$ The "molar tooth sign" (MTS) seen on MRI scans is characteristic and diagnostic of JBTS, and is caused by a complex midbrain-hindbrain abnormality. ${ }^{27}$ Five loci have been identified to date (JBTS1-5). JBTS1 has been mapped to chromosome 9q34.3 but no causative gene 
has yet been identified. ${ }^{28}$ Patients with JBTS1 linkage tend to have features restricted to the CNS, particularly the cerebellar and the midbrain-hindbrain junction. ${ }^{29}$ A novel locus for JBTS, JBST2, has been mapped to chromosome 11p11.2-q12.3.30 31 Valente et al showed that, unlike patients with JBTS1 linkage, patients with JBST2 linkage present with multi-organ involvement including the kidney, brain and retina, in addition to the typical CNS abnormalities, and the phenotype has also been described as "cerebellar-ocular-renal syndrome" (CORS) ${ }^{29}$ No causative gene at this locus has yet been identified. JBTS3 is found at chromosome 6q23.3, with pathogenic mutations identified in the gene AHI1, which encodes a novel protein, jouberin, that contains a $\mathrm{N}$-terminal coiled-coil domain. ${ }^{32}$ Patients with mutations in AHI1 typically have features that are restricted to the CNS. The fourth JBTS locus was identified in a subset of patients presenting with juvenile nephronophthisis (NPHP) in combination with typical CNS abnormalities. The gene NPHP1, on chromosome $2 \mathrm{q} 13$, was identified as causing this distinctive phenotype. ${ }^{33}$ A fifth JBTS locus, JBTS5, has been mapped to chromosome 12q21.3, because of the recent identification of mutations in the NPHP6/CEP290 gene, and encodes the $290 \mathrm{kDa}$ centrosomal protein CEP290. ${ }^{33}{ }^{34}$ Patients with NPHP6/CEP290 mutations have a variable phenotype with neurological and neuroradiological features of JBTS, but also severe retinal and renal involvement. ${ }^{34}$ Remarkably, mutations in NPHP6/CEP290 have also been associated with a range of phenotypes that include MKS and Leber congenital amaurosis (LCA). ${ }^{36}{ }^{37}$

A variety of other abnormalities has been described in children with JBTS, with different levels of severity, including a characteristic facial appearance, delayed language, hypersensitivity to noise, autism, ocular and oculomotor abnormalities, meningoencephaloceles, microcephaly, low-set ears, polydactyly, retinal dysplasia, kidney abnormalities (renal cysts), softtissue tumours of the tongue, liver disease (including fibrocystic changes) and duodenal atresia. ${ }^{38}$ Several of these features overlap with those described for MKS including, in particular, the classic MKS features of polydactyly, fibrocystic changes to the liver and encephalocele. Owing to the phenotypic overlap between MKS and JBTS, it was hypothesised that the two separate diseases might in fact be allelic, with pathogenic mutations in the same gene. This has subsequently been shown for the NPHP6/CEP290 gene, with mutations causing a Meckel-like cerebrorenodigital syndrome. A novel form of CORS, with additional craniofacial abnormalities such as cleft palate and small jaw, is caused by mutations in the RPGRIP1L/KIAA1005 gene..$^{36}{ }^{39}$ Furthermore, mutations in the MKS3/TMEM67 gene can cause both an MKS phenotype and JBTS. ${ }^{40}{ }^{41}$ In addition, there is a strong genotype-phenotype correlation for mutations at the MKS3 and MKS1, with marked differences in the frequency of polydactyly and the severity of CNS malformations. ${ }^{42} 43$ The severity of the MKS and JBTS spectrum of phenotypes has been suggested to be due to a complete absence of cilia in affected tissues. ${ }^{44} \mathrm{~A}$ very recent and unexpected finding has come from two genome-wide association studies for both adult and childhood obesity. ${ }^{45}{ }^{46}$ Frayling et al studied type 2 diabetes and found that a common variant in the FTO (fat mass and obesity associated) gene contributed to obesity. ${ }^{45}$ They pointed out that the first intron of FTO is also part of the control region for the RPGRIP1L/KIAA1005 gene. RPGRIP1L/KIAA1005 may therefore be implicated in not only the rare, mendelian disorders of MKS and JBTS, but also a common, multifactorial disease such as obesity.

\section{THE ROLE OF CILIARY PROTEINS IN CILIOGENESIS}

For a cilium to form in the right locale and to function correctly, several criteria have to be met. In the first instance, the cell has to exhibit a polar orientation with respect to the external cell environment (fig 1). This is established by the formation of intercellular junctions with adjacent cells along the basolateral surface, creating a sheet of epithelial cells. These junctions, known as tight junctions in vertebrates, serve to separate membrane compartments and thus create a diffusion barrier between those compartments. In the kidney, these sheets form tubules through which urine flow is monitored by primary cilia. Proteins implicated in ciliopathies have been shown to exist in complexes with tight junction proteins or other junctional complexes (such as adherens junctions), or to have an association with the basolateral surface before cilia formation. The protein nephrocystin, encoded by the NPHP1 gene (table 1), has a partial localisation with $\beta$-catenin, and isoforms of inversin (encoded by the INVS/NPHP2 gene) also associate with $\mathrm{N}$-cadherin and catenins. ${ }^{47}{ }^{48}$ This overlap in subcellular location implies that these proteins exist as part of conserved multifunctional complexes, a common theme in many ciliopathies. ${ }^{49}{ }^{50}$ Evidence for a "nephrocystin complex" is provided by in vitro biochemical experiments that show specific interactions of nephrocystin with nephrocystin- $4 .{ }^{47}$ Proteins lost or defective in PKD may also be involved in cell-cell contacts, as both fibrocystin/polyductin and polycystin-2 localise with E-cadherin at adherens junctions and may be involved in stabilisation of the actin cytoskeleton across the epithelial cell layer. ${ }^{16}$

Tight junction complexes are crucial components for maintenance of cell polarity, and serve as anchoring points for the cell's cytoskeletal architecture. The cytoskeleton consists of

A

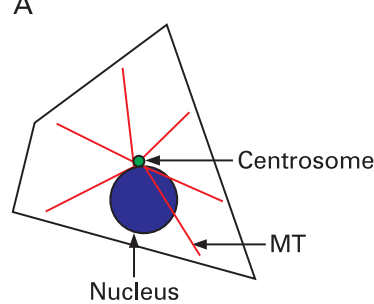

B
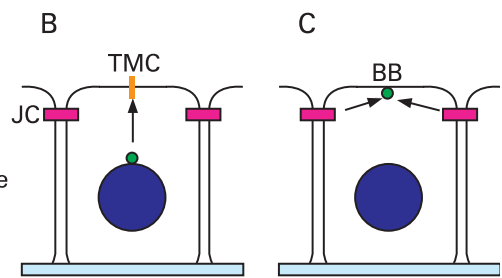

D

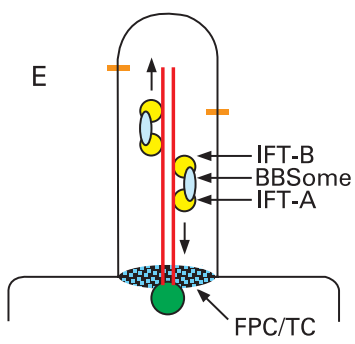

Figure 1 Ciliogenesis and structure of the mature cilium (A) A nonpolarised epithelial cell showing positions of the nucleus (blue), the centrosome (green) and a simplified microtubule array focused on the centrosome or microtubule organising centre (MTOC; red). (B). A polarised post-mitotic epithelial cell forming part of a cell layer anchored into place by junctional complexes (JC; pink), such as tight junctions.

The centrosome migrates towards the apical cell surface (arrow) where it anchors with a transmembrane protein or complex (TMC; orange) to form the basal body (BB), seen in position in (C). Cilia precursor proteins then migrate from the junctional complexes to the basal body (arrows) where they initiate cilia growth via intraflagellar transport (IFT) (D, arrow). An intact mature cilium is seen in (F) showing the location of the flagellar pore complex/transition zone (FPC/TZ) and retrograde/antiretrograde movement (arrows) of IFT complexes $A$ and $B$, linked via the BBSome. 
Figure 2 Immunofluoresence microscopy of ciliated IMCD3 cells. Top, location of (left) meckelin; (middle) acetylated- $\alpha$-tubulin (the axoneme) and (right) a merged image confirming presence of meckelin (green) along the axoneme (red) (bar: $5 \mu \mathrm{m}$ ). Middle, the location of (left) IFT80, (middle) acetylated- $\alpha$-tubulin (the axoneme) and (right) a merged image confirming punctate distribution of IFT particles (green) along the axoneme (red) (bar: $5 \mu \mathrm{m})$. Bottom, distribution of (left) basolateral actin (bar: $10 \mu \mathrm{m}$ ) and (right) $\gamma$-tubulin, indicating position of the basal body (bar: $10 \mu \mathrm{m}$ ).
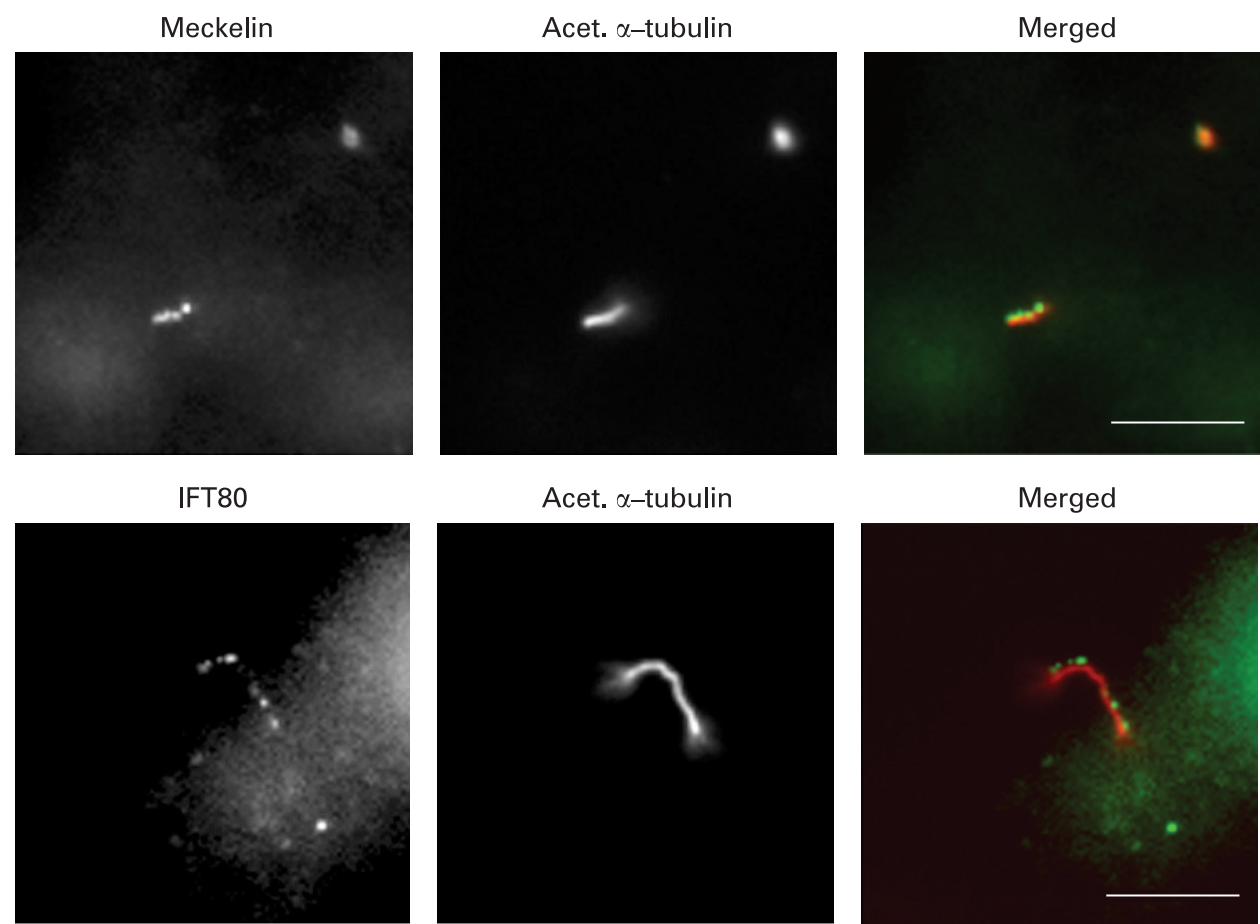

Actin
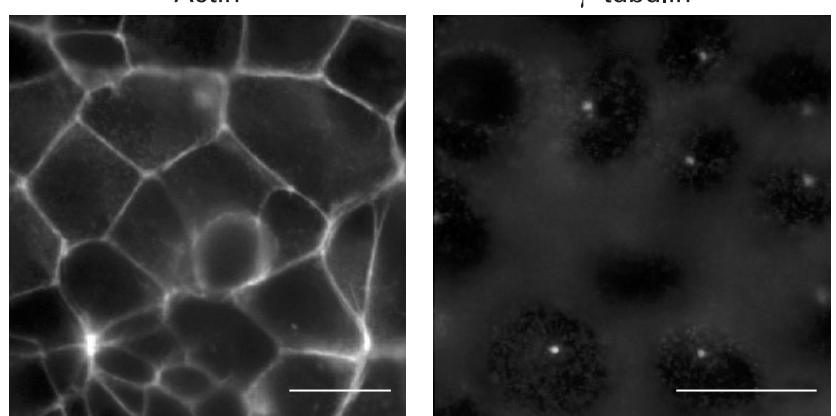

actin filaments, intermediate filaments and microtubules, and both the actin and microtubule networks have specific roles in cilia or ciliogenesis. Of particular importance is the microtubule network, which forms an array centred around the centrosome; this array is considered the microtubule organising centre (MTOC; fig 1). In proliferating cells, the centrosome is crucial in mediating mitosis and forming the poles of the mitotic spindle. Although aberrant proliferation occurs in the development of cysts within the kidney, and inversin and polycystin localise to the mitotic spindle, it is unclear whether there is a direct role for a nephrocystin complex in proliferation. More convincing is a trafficking role towards the centrosome/basal body, mediated by the microtubule motor protein kinesin $2 .{ }^{51} 52$ KIF3A is a subunit of kinesin 2, which, when inactivated in mice, results in PKD, whereas a second subunit, KIF3B, exists as a complex with polycystin 2 and fibrocystin/polyductin. Kinesins also have a role in intact cilia, and mediate transport along the axoneme. ${ }^{53-55}$

After the establishment of polarity, the centrosome is required to migrate to the apical cell surface where it docks before basal body formation and cilia growth (fig 1). This occurs by an unknown process, but in multiciliated airway epithelia, the actin cytoskeleton is implicated in basal body migration. ${ }^{56}$ In addition, as the interphase centrosome is positioned by microtubules, a role for the microtubule cytoskeleton cannot be discounted. Centrosomal migration may also be mediated by proteins involved in cell polarity. ${ }^{57}$ Loss of MKS1 or meckelin negates centrosome movement and docking at the apical surface. MKS1 has been shown to localise to the centrosome/ basal body although meckelin, at the early stages of ciliogenesis, localises to the apical cell surface. Meckelin is a transmembrane receptor, and co-immunoprecipitation experiments have shown that it can exist in the same complex as MKS1. This interaction implies that meckelin may be responsible for docking of the centrosome at the apical surface. ${ }^{14}$ Loss of this interaction results in complete absence of the cilia and may therefore account for the relative severity of the MKS phenotype. ${ }^{44}$ The CEP290 protein (table 1) has also been shown to localise to the pericentriolar matrix (PCM) in preciliated cells and to the basal body in ciliated cells. ${ }^{35}$ This is in common with other PCM proteins, which translocate to a more focussed point after basal body formation. ${ }^{58}$ Polycystin 2 has been shown to associate with pericentrin at the basal body, which may direct the nephrocystin/polycystin complex to the cilia after it is transported from the basolateral surface..$^{59}$ Centriolar/basal body components may also serve to direct BBS4 and BBS6 to the cilium. ${ }^{61}{ }^{62}$ Nephrocytin-4 also interacts with the protein produced by the RPGRIP1L gene (table 1) at the basal body. ${ }^{63}$ 


\section{INTRAFLAGELLAR TRANSPORT AND ASPHYXIATING THORACIC DYSTROPHY}

The apical localisation of cilia-related proteins and precursors at the basal body may be necessary for cilia initiation, and is a process that relies upon intraflagellar transport (IFT) by kinesins. ${ }^{16}{ }^{65}$ IFT is the process by which protein complexes, called IFT particles, are transported bidirectionally along the axoneme of cilia and flagella by the coordinated action of IFT motors (figs 1, 2). ${ }^{53-556566} \mathrm{~A}$ probable initial stage in ciliogenesis is that the basal body forms the template for the ciliary axoneme, and the structure of the basal body complex accounts for the radial array of microtubules within the cilium. The axoneme is essentially the cilia "backbone", which remains attached in intact cilia and consists of a polarised array of microtubules extending from the basal body to the ciliary tip. The tubulin within the axoneme is a long-lived stable subtype, which is post-translationally modified by acetylation (fig 2). Cilia growth and maintenance is achieved by the movement of proteins along this acetylated tubulin track as part of large vesicular complexes or particles, which comprise the IFT complexes. . $^{53-556566}$ Ciliary protein precursors enter the cilia through a flagellar pore complex or transition zone at the base of the cilia (fig 1). It has been suggested that nephrocystin has a role at this location because of the overlapping distribution of nephrocystins at the basal body/transition zone, which may be a loading point before transport through the flagellar pores. ${ }^{47}{ }^{67}$ Proteins are then associated with IFT particles and are transported along the axoneme via microtubule motor complexes; kinesins towards the tip (anterograde transport) and dyneins to the base for recycling (retrograde transport). Certain cell types, such as photoreceptor cells, rely on IFT for transport of proteins and lipids between the inner and outer segments along the connecting cilium. ${ }^{69}$ It is therefore not surprising that defects in intersegmental transport in photoreceptors, due to dysfunction or absence of a ciliary or basal body protein, can give rise to a loss-of-vision phenotype in many ciliopathies. Retinitis pigmentosa or blindness due to retinal degeneration is a feature of BBS, the CORS form of JBTS and the Senior-Løken syndrome (SLS) form of nephronophthisis (table 1).

IFT proteins were first identified as essential factors for the growth and maintenance of flagella in the single-celled algae Chlamydomonas reinhardtii. The flagellum of this eukaryote is composed of $>360$ proteins that must be transported and assembled into various structures precisely along the microtubules. ${ }^{69} 70$ IFT particles can be isolated by subcellular fractionation and separated into two classes by sucrose gradient centrifugation. These size classes are called complexes A and B. ${ }^{6}$ Complex A is composed of at least five polypeptides (IFT144, IFT140, IFT139, IFT122A, IFT122B and possibly IFT43), and complex $B$ is composed of at least 12 different polypeptides (IFT172, IFT88, IFT81, IFT80, IFT74, IFT75, IFT55, IFT57, IFT52, IFT46, IFT27 and IFT20), of relative mass ranging from 20 to $172 \mathrm{kDa}$ (reviewed by $\mathrm{Cole}^{71}$ ). Mutations in either complex A or complex B genes cause short, absent or stumpy flagella. For example, mutant C. reinhardtii lacking IFT88 have a normal cell phenotype but their flagella do not assemble and they are described as "bald". ${ }^{69}$ An insertion mutation in the mouse homologue, $\operatorname{Tg} 737$, encoding the protein polaris, gave rise to a phenotype resembling ARPKD, first described in the orpk (Oak Ridge polycystic kidney disease) mouse. ${ }^{72}$ The phenotype of the homozygous mutated mice included bilateral polycystic kidneys, abnormal outer segment development and retinal degeneration, which resulted in premature death within a few weeks of birth. ${ }^{69}$ Subsequently, the human homologue, TG737/
TTC10, at chromosome 13q12.1, was characterised and suggested as a candidate gene for ARPKD, but subsequent screening of patients with ARPKD has found no mutations in this gene. ${ }^{73}$

To date, asphyxiating thoracic dystrophy (ATD; also known as Jeune syndrome) is the only human ciliopathy that is associated with mutations in an IFT protein homologue. ATD is an autosomal recessive chondrodysplasia, which often leads to death in infancy because of a severely constricted thoracic cage and respiratory insufficiency. Retinal degeneration, cystic renal disease and polydactyly are other common features. Mutations in IFT80/ WDR 56 were identified in a small subset $(10 \%)$ of ATD families without extraskeletal manifestations, which suggests that further genetic heterogeneity in ATD is likely to be caused by mutations in other IFT-associated genes. ${ }^{74}$ A possible candidate is IFT57, which is reported to localise with polycystin- $2 .{ }^{59}$

\section{GENETIC HETEROGENEITY: NEPHRONOPHTHISIS AND BARDET- BIEDL SYNDROME}

One obvious characteristic of the ciliopathies is the extensive genetic heterogeneity for conditions such as nephronophthisis (NPHP) and BBS (BBS; table 1). NPHP is an autosomal recessive cystic kidney disease and is the most common genetic cause of end-stage renal failure in first three decades of life. Five causative genes have been identified to date (table 1; reviewed by Hildebrandt et $a^{75}$ ). BBS is an autosomal recessive pleiotropic condition with multiorgan involvement and variable severity. It is characterised by obesity, retinal degeneration, polydactyly, renal and gonadal malformation and behavioural and developmental problems. ${ }^{76}$ Twelve BBS-associated genes have been identified to date (table 1). At least seven of the encoded proteins (BBS1, 3, 4, 5, 6, 7 and 8) are known to associate with either the centriole/basal body or the axoneme of primary cilia. In both of these examples, the genetic heterogeneity implies that the encoded NPHP or BBS proteins could be components of either a common pathway or a multisubunit complex. ${ }^{77}$ The BBS proteins have now been shown to interact in a multisubunit complex known as the "BBSome"; BBS4 forms a complex with BBS 1, 2, 5, 7, 8, and 9, with BBS9 acting as a possible organising subunit. ${ }^{44}$ This observation provides a mechanistic explanation for both the potential epistatic interactions of BBS genes, and the wide variability in the severity of the phenotype. Katsanis et al. identified three mutations in both the BBS2 and BBS6 genes in affected members of three pedigrees, with an inheritance pattern that they suggested was triallelic. ${ }^{78} \mathrm{BBS}$ can also be considered a monogenic recessive disease, with heterozygous mutations at a second BBS gene modifying severity of the phenotype. For example, three families, with two mutations in either BBS1 or BBS2, had some but not all patients carrying a third heterozygous mutation in $B B S 1, B B S 2$ or $B B S 6 .^{79}$ Stoetzel et al. found that a minority (18\%) of families with BBS10 mutations also had mutations or recognised variants (predominantly missense changes) at another BBS locus. ${ }^{80}$ The most compelling examples from this report were two families that each had affected patients with two BBS10 mutations and one additional pathogenic BBS1 mutation, and, a third family that, conversely, had a single $B B S 10$ frameshift mutation carrying two pathogenic BBS1 mutations. Further evidence of the oligogenic inheritance pattern of $\mathrm{BBS}$ has come from the identification of a novel locus, MGC1203/CCDC28B, which contributes epistatic alleles to $\mathrm{BBS}^{81}$ The encoded protein, coiled-coil domain-containing protein $28 \mathrm{~B}$ (CCDC28B), is a pericentriolar protein, and interacts with the BBS1, 2, 4, 5, 6, 7 and 8 . It is possible that 
the penetrance of other ciliopathies may be modified in a similar fashion.

The BBS7 and BBS8 proteins have been shown to be crucial for normal IFT of components along the axoneme of primary cilia, and the distribution of BBS4 shows motility along the axoneme similar to IFT (fig 1). ${ }^{82}$ A possible role for BBS proteins in ciliary assembly and disassembly is suggested from observations of BBS proteins at centriolar satellites in non-ciliated cells, followed by translocation during cilia formation to primary cilia. BBS4 localises with PCM1, which is normally absent from cilia, and the loss of PCM1 leads to the disappearance of centriolar satellites, disruption of centrosomes and diminished cilia formation. ${ }^{44}{ }^{58}$ BBS1 associates with the vesicular trafficking protein Rabin-8, the loss of which leads to depleted ciliation and disruption of BBS4 localisation in pre-ciliated cells. The normal function of Rabin-8 at the basal body appears to be the activation of proteins that migrate to the cilia and are involved in cilia elongation. Depletion of BBS1 and BBS5 proteins result in the most severe phenotype, with PCM1 and BBS4 still localised to centriolar satellites, and centrin and pericentrin are still targeted to the centrosome, but ciliation being dramatically reduced. Once inside the cilium, it is plausible that the BBSsome may act as an IFT cohesion factor responsible for linking IFT-A with IFT-B (fig 1)..$^{44}$

\section{SIGNALLING PATHWAYS MEDIATED BY PRIMARY CILIA}

It is now understood that IFT not only serves to assemble and maintain the structure of the cilia and flagella, but is also involved in signalling. Cole et al showed that mutations affecting IFT particle polypeptides in C. elegans result in defects in the sensory cilia located on sensory neurons. ${ }^{66}$ Recent studies have suggested that IFT has an important role in vertebrate Sonic Hedgehog (Shh) signalling. Two mouse mutants, wimple (wim) and flexo (fxo), lack ventral neural cell types and show other phenotypes characteristic of defects in Shh signalling. Both mutations disrupt IFT proteins: the wim mutation is an allele of the previously uncharacterised mouse homologue of IFT172, and fxo is a hypomorphic allele of polaris, the mouse homologue of IFT88. Genetic analysis showed that Wim, Polaris and the IFT motor protein Kif3a are required for Hedgehog signalling at a step downstream of Patched1 (the Hedgehog receptor) and upstream of direct targets of Hedgehog signalling. ${ }^{83}$ Beales et al also investigated the role of ift80 during zebrafish embryonic development, and suggested that it acts downstream of ptc1 (the zebrafish Hedgehog receptor) in the Shh pathway. ${ }^{74}$ Cilia are therefore clearly used as sensory organelles in lower eukaryotes, and are likely to have the same role in mammals. Aberrant signalling is also hypothesised as a pathogenesis for MKS. Meckelin is a ciliary surface transmembrane protein (fig 2) with predicted topological similarity to the frizzled family of receptor proteins, which have diverse roles in signal transduction and tissue morphogenesis.

Polycystin-1 and fibrocystin/polyductin are both implicated in signal transduction pathways, albeit with different effects. Loss of polycystin-1 activates a signalling pathway, whereas loss of fibrocystin inactivates a pathway and results in loss of ligand secretion. Polycystin-1 undergoes proteolytic cleavage, resulting in nuclear translocation of cytoplasmic tail. This domain interacts with transcription factor STAT6 and the coactivator P100 to stimulate STAT6-dependent gene expression and epithelial cell proliferation. In intact cilia with normally functioning polycystins, STAT6 is localised along the axoneme. During cyst formation, renal epithelial cells proliferate and eventually replace most of the normal renal tissue, resulting in loss of apical fluid flow and in aberrant mechanosenation. In cyst-lining cells, STAT6 predominantly has a nuclear localisation. ${ }^{12}{ }^{84}$ Fibrocystin is a membrane-spanning protein that also undergoes post-translational proteolytic cleavage. Through the activity of ADAM sheddases, the external domain is released into the extracellular space, where it may act as a ligand for other receptors. In addition, the fibrocystin C-terminus is also cleaved but translocates to the nucleus. Importantly, the proteolysis of fibrocystin is dependent upon the influx of intracellular calcium, a process requiring intact functioning and localisation of the polycystins. Polycystin-2 is an ion channel, the activity of which is necessary for calcium influx during sensation of fluid flow. ${ }^{11} 8586$ This activity may be regulated by its binding partners, polycystin-1 and fibrocystin. ${ }^{16}{ }^{65}$ The function of this complex at the plasma membrane and the cilium may be highly tissue-specific and depend upon the level of expression. High expression is seen in the kidney and may account for the presentation of kidney-specific defects when these proteins are mutated. ${ }^{87} 88$ The function of this complex underlies a key mechanosensory role for cilia, which ultimately regulate tissue morphogenesis. Shear stress caused by fluid flow in the kidney tubule causes bending of the cilia at a point where this complex is localised. A conformational change within the complex may activate polycystin-2, resulting in the influx of calcium, which mediates signalling to adjacent cells via intercellular junctions. Alterations in the subtle relationships between polycystins and fibrocystin account for the similar phenotypes when these proteins are mutated in PKD. Dysfunction results in the formation of renal cysts as the cells cannot sense normal mechanical cues. An intriguing observation is that this loss of mechanosensation does not affect ciliogenesis or cilia length, which is a situation also seen with the nephrocystins. ${ }^{16} 678990$ The implication of this, alongside the kidney-specific pathologies, is that mutations in these complexes may not affect cilia function in most other organs. However, there is evidence that the function of this complex may be aberrant within other ciliopathies. An association of polycystin-2 with IFT57, which would indirectly associate this complex with the BBS phenotype, has been reported, and localisation with pericentrin at the centrosome/basal body has implications for many other ciliopathies. ${ }^{59}$

\section{CONCLUSIONS AND PERSPECTIVES}

Primary cilia are vital cellular components for chemosensation and mechanosensation. Ciliopathies, such as MKS, JBTS and ALMS, are characterised by the complete or partial loss of these cilia, and their expressed phenotypes vary accordingly. The broad spectrum of phenotypes observed in the ciliopathies is indicative of the extensive roles cilia play in the development of many tissue types, including kidney, brain, liver, eyes and bone. Genetic heterogeneity is a common feature in ciliopathies, with mutant genes giving rise to differing disorders, thus making their identification and characterisation all the more elusive. At least 12 genes are associated with $\mathrm{BBS}$, leading to speculation that their products are components of a common pathway or complex. Moreover, it is likely that all of the proteins involved in the ciliopathies are linked through their interactions in the same pathways and complexes. Ciliary proteins tend to exist in complexes at various cellular locations, mediating processes such as the formation of intercellular junctions, cell-cell contacts, and centrosome movement. IFT motors coordinate the transportation of ciliary protein complexes, thereby facilitating cilia growth and maintenance. Mutations in IFT genes result in absent or shortened cilia, but ATD (Jeune syndrome) is 
the only characterised example of this in humans. IFT also appears to be involved in Sonic Hedgehog signalling, any disruption of which can have potentially severe developmental consequences.

A number of well-characterised flagellar proteomes have been described recently (reviewed in Gherman et $a^{6}$; also refer to www.ciliaproteome.org). These include the flagellar proteome of the flagellated protozoan parasite Trypanosoma brucei (the trypanosome flagellar proteome), a human airway proteome, and the Tetrahymena proteome. ${ }^{91-93}$ Although primary cilia have not yet been analysed at the proteomics level, a recent study has identified 1968 proteins in the specialised mouse photoreceptor sensory cilium or outer segment. ${ }^{94}$ In addition, Pazour et a $l^{5}$ used a comparative genomics strategy to identify 688 genes present exclusively in organisms with flagella and basal bodies, which led to the identification of the BBS5 gene. These proteomes and datasets will be invaluable for future studies of how cilia are built and maintained, and how these processes are disrupted in human disease. In addition, they will direct future gene identification studies for several developmental disorders that are presumed to be ciliopathies, but for which causative genes have not yet been identified. Probable such ciliopathies include Ivemark syndrome (renal-hepatic pancreatic dysplasia) and, by analogy with ATD, the short rib polydactyly syndromes (SRPSs). Even for the known ciliopathies, the extensive genetic heterogeneity of most of the conditions means that there are still new loci to be mapped and new genes waiting to be identified. The remarkable progress made in the past 5 years guarantees that we can look forward to some exciting insights in the future.

Acknowledgements: We thank Professor $\mathrm{C}$ Inglehearn for helpful discussions. The IFT80 antiserum used for fig 2 was the kind gift of Professor P Scambler, Institute of Child Health, London. CAJ is supported by BDF Newlife and the Medical Research Council.

\section{Competing interests: None.}

\section{REFERENCES}

1. Zimmerman KW. Beitrage zur kenntniss einiger drusen und epithelien. Arch Mikrosk Anat 1898;52:552-706.

2. Dawe HR, Farr H, Gull K. Centriole/basal body morphogenesis and migration during ciliogenesis in animal cells. J Cell Sci 2007;120:7-15

3. Ward CJ, Yuan D, Masyuk TV, Wang X, Punyashthiti R, Whelan S, Bacallao R, Torra R, LaRusso NF, Torres VE, Harris PC. Cellular and subcellular localization of the ARPKD protein; fibrocystin is expressed on primary cilia. Hum Mol Genet 2003;12:2703-10.

4. Mochizuki T, Saijoh Y, Tsuchiya K, Shirayoshi Y, Takai S, Taya C, Yonekawa H, Yamada K, Nihei H, Nakatsuji N, Overbeek PA, Hamada H, Yokoyama T. Cloning of inv, a gene that controls left/right asymmetry and kidney development. Nature 1998:395:177-81.

5. Li JB, Gerdes JM, Haycraft CJ, Fan Y, Teslovich TM, May-Simera H, Li H, Blacque OE, Li L, Leitch CC, Lewis RA, Green JS, Parfrey PS, Leroux MR, Davidson WS, Beales PL, Guay-Woodford LM, Yoder BK, Stormo GD, Katsanis N, Dutcher SK. Comparative genomics identifies a flagellar and basal body proteome that includes the BBS5 human disease gene. Cell 2004;117:541-52.

6. Gherman A, Davis EE, Katsanis N. The ciliary proteome database: an integrated community resource for the genetic and functional dissection of cilia. Nat Genet 2006;38:961-2.

7. Badano JL, Mitsuma N, Beales PL, Katsanis N. The Ciliopathies: An Emerging Class of Human Genetic Disorders. Annu Rev Genomics Hum Genet 2006;7:125-48.

8. Zariwala MA, Knowles MR, Omran H. Genetic defects in ciliary structure and function. Annu Rev Physiol 2007;60:423-50.

9. Smith EF. Hydin seek: finding a function in ciliary motility. J Cell Biol 2007;176

10. Johnson CA, Gissen P, Sergi C. Molecular pathology and genetics of congenital hepatorenal fibrocystic syndromes. J Med Genet 2003;40:311-19.

11. Nauli SM, Alenghat FJ, Luo Y, Williams E, Vassilev P, Li X, Elia AE, Lu W, Brown EM, Quinn SJ, Ingber DE, Zhou J. Polycystins 1 and 2 mediate mechanosensation in the primary cilium of kidney cells. Nat Genet 2003;33:129-37.

12. Kaimori JY, Nagasawa Y, Menezes LF, Garcia-Gonzalez MA, Deng J, Imai E, Onuchic LF, Guay-Woodford LM, Germino GG. Polyductin undergoes notch-like processing and regulated release from primary cilia. Hum Mol Genet 2007;16:94256 .
13. den Hollander Al, Koenekoop RK, Mohamed MD, Arts HH, Boldt K, Towns KV, Sedmak T, Beer M, Nagel-Wolfrum K, McKibbin M, Dharmaraj S, Lopez I, Ivings L, Williams GA, Springell K, Woods CG, Jafri H, Rashid Y, Strom TM, van der Zwaag B, Gosens I, Kersten FF, van Wijk E, Veltman JA, Zonneveld MN, van Beersum SE, Maumenee IH, Wolfrum U, Cheetham ME, Ueffing M, Cremers FP, Inglehearn CF, Roepman R. Mutations in LCA5, encoding the ciliary protein lebercilin, cause Leber congenital amaurosis. Nat Genet 2007;39:889-95.

14. Dawe HR, Smith UM, Cullinane AR, Gerrelli D, Cox P, Badano JL, Blair-Reid S, Sriram N, Katsanis N, Attie-Bitach T, Afford SC, Copp AJ, Kelly DA, Gull K, Johnson CA. The Meckel-Gruber Syndrome proteins MKS1 and meckelin interact and are required for primary cilium formation. Hum Mol Genet 2007;16:173-86.

15. Kyttala M, Tallila J, Salonen R, Kopra O, Kohlschmidt N, Paavola-Sakki P, Peltonen L, Kestila M. MKS1, encoding a component of the flagellar apparatus basal body proteome is mutated in Meckel syndrome. Nat Genet 2006;38:155-7.

16. Wang S, Zhang J, Nauli SM, Li X, Starremans PG, Luo Y, Roberts KA, Zhou J. Fibrocystin/polyductin, found in the same protein complex with polycystin-2, regulates calcium responses in kidney epithelia. Mol Cell Biol 2007;27:3241-52.

17. Hildebrandt F, Zhou W. Nephronophthisis-associated ciliopathies. J Am Soc Nephrol 2007;18:1855-71.

18. Snell WJ, Pan J, Wang 0. Cilia and flagella revealed: from flagellar assembly in Chlamydomonas to human obesity disorders. Cell 2004;117:693-7.

19. Hearn T, Renforth GL, Spalluto C, Hanley NA, Piper K, Brickwood S, White C, Connolly V, Taylor JF, Russell-Eggitt I, Bonneau D, Walker M, Wilson DI. Mutation of ALMS1, a large gene with a tandem repeat encoding 47 amino acids, causes Alstrom syndrome. Nat Genet 2002;31:79-83.

20. Collin GB, Marshall JD, Ikeda A, So WV, Russell-Eggitt I, Maffei P, Beck S, Boerkoel CF, Sicolo N, Martin M, Nishina PM, Naggert JK. Mutations in ALMS1 cause obesity, type 2 diabetes and neurosensory degeneration in Alstrom syndrome. Nat Genet 2002;31:74-8.

21. Hearn T, Spalluto C, Phillips VJ, Renforth GL, Copin N, Hanley NA, Wilson DI. Subcellular localization of ALMS1 supports involvement of centrosome and basal body dysfunction in the pathogenesis of obesity, insulin resistance, and type 2 diabetes. Diabetes 2005; 54:1581-7.

22. Collin GB, Cyr E, Bronson R, Marshall JD, Gifford EJ, Hicks W, Murray SA, Zheng OY, Smith RS, Nishina PM, Naggert JK. Alms1-disrupted mice recapitulate human Alstrom syndrome. Hum Mol Genet 2005;14:2323-33.

23. Li G, Vega R, Nelms K, Gekakis N, Goodnow C, McNamara P, Wu H, Hong NA Glynne R. A role for Alstrom syndrome protein, alms1, in kidney ciliogenesis and cellular quiescence. PLoS Genet 2007;3:e8.

24. Ferrante MI, Giorgio G, Feather SA, Bulfone A, Wright V, Ghiani M, Selicorni A, Gammaro L, Scolari F, Woolf AS, Sylvie O, Bernard L, Malcolm S, Winter R, Ballabio A, Franco B. Identification of the gene for oral-facial-digital type I syndrome. Am J Hum Genet 2001;68:569-76.

25. Romio L, Fry AM, Winyard PJ, Malcolm S, Woolf AS, Feather SA. OFD1 is a centrosomal/basal body protein expressed during epithelial-mesenchymal transition in human nephrogenesis. J Am Soc Nephrol 2004;15:2556-68.

26. Joubert M, Eisenring JJ, Robb JP, Andermann F. Familial agenesis of the cerebellar vermis. A syndrome of episodic hyperpnea, abnormal eye movements, ataxia, and retardation. Neurology 1969;19:813-25.

27. Patel S, Barkovich AJ. Analysis and classification of cerebellar malformations. AJNR Am J Neuroradiol. 2002;23:1074-87.

28. Saar K, Al-Gazali L, Sztriha L, Rueschendorf F, Nur EKM, Reis A, Bayoumi R. Homozygosity mapping in families with Joubert syndrome identifies a locus on chromosome 9q34.3 and evidence for genetic heterogeneity. Am J Hum Genet 1999;65:1666-71.

29. Valente EM, Marsh SE, Castori M, Dixon-Salazar T, Bertini E, Al-Gazali L, Messer J, Barbot C, Woods CG, Boltshauser E, Al-Tawari AA, Salpietro CD, Kayserili H, Sztriha L, Gribaa M, Koenig M, Dallapiccola B. and Gleeson JG. Distinguishing the four genetic causes of Jouberts syndrome-related disorders. Ann Neurol 2005;57:51319.

30. Valente EM, Salpietro DC, Brancati F, Bertini E, Galluccio T, Tortorella G, Briuglia S Dallapiccola B. Description, nomenclature, and mapping of a novel cerebello-renal syndrome with the molar tooth malformation. Am J Hum Genet 2003;73:663-70.

31. Keeler LC, Marsh SE, Leeflang EP, Woods CG, Sztriha L, Al-Gazali L, Gururaj A, Gleeson JG. Linkage analysis in families with Joubert syndrome plus oculo-renal involvement identifies the CORS2 locus on chromosome 11p12-q13.3. Am J Hum Genet 2003;73:656-62.

32. Ferland RJ, Eyaid W, Collura RV, Tully LD, Hill RS, Al-Nouri D, Al-Rumayyan A, Topcu M, Gascon G, Bodell A, Shugart YY, Ruvolo M, Walsh CA. Abnormal cerebellar development and axonal decussation due to mutations in AHI1 in Joubert syndrome. Nat Genet 2004;36:1008-13.

33. Parisi MA, Bennett CL, Eckert ML, Dobyns WB, Gleeson JG, Shaw DW, McDonald R, Eddy A, Chance PF, Glass IA. The NPHP1 gene deletion associated with juvenile nephronophthisis is present in a subset of individuals with Joubert syndrome. Am J Hum Genet 2004;75:82-91.

34. Sayer JA, Otto EA, O'Toole JF, Nurnberg G, Kennedy MA, Becker C, Hennies HC Helou J, Attanasio M, Fausett BV, Utsch B, Khanna H, Liu Y, Drummond I, Kawakami I, Kusakabe T, Tsuda M, Ma L, Lee H, Larson RG, Allen SJ, Wilkinson CJ Nigg EA, Shou C, Lillo C, Williams DS, Hoppe B, Kemper MJ, Neuhaus T, Parisi MA Glass IA, Petry M, Kispert A, Gloy J, Ganner A, Walz G, Zhu X, Goldman D, Nurnberg $P$, Swaroop A, Leroux MR, Hildebrandt F. The centrosomal protein nephrocystin-6 is mutated in Joubert syndrome and activates transcription factor ATF4. Nat Genet 2006;38:674-81. 
35. Valente EM, Silhavy JL, Brancati F, Barrano G, Krishnaswami SR, Castori M, Lancaster MA, Boltshauser E, Boccone L, Al-Gazali L, Fazzi E, Signorini S, Louie CM, Bellacchio E, Bertini E, Dallapiccola B, Gleeson JG.Mutations in CEP290, which encodes a centrosomal protein, cause pleiotropic forms of Joubert syndrome. Nat Genet 2006;38:623-5.

36. Baala L, Audollent S, Martinovic J, Ozilou C, Babron MC, Sivanandamoorthy S, Saunier S, Salomon R, Gonzales M, Rattenberry E, Esculpavit C, Toutain A, Moraine C, Parent P, Marcorelles P, Dauge MC, Roume J, Le Merrer M, Meiner V, Meir K, Menez F, Beaufrere AM, Francannet C, Tantau J, Sinico M, Dumez Y, MacDonald F, Munnich A, Lyonnet S, Gubler MC Genin E, Johnson CA, Vekemans M, Encha-Razavi F, Attie-Bitach T. Pleiotropic effects of CEP290 (NPHP6) mutations extend to Meckel syndrome Am J Hum Genet 2007;81:170-9.

37. den Hollander Al, Koenekoop RK, Yzer S, Lopez I, Arends ML, Voesenek KE, Zonneveld MN, Strom TM, Meitinger T, Brunner HG, Hoyng CB, van den Born LI, Rohrschneider K, Cremers FP. Mutations in the CEP290 (NPHP6) gene are a frequent cause of Leber congenital amaurosis. Am J Hum Genet 2006;79:556-61.

38. Kumandas, S, Akcakus M, Coskun A, Gumus H. Joubert syndrome: review and report of seven new cases. Eur J Neurol 2004;11:505-10.

39. Delous M, Baala L, Salomon R, Laclef C, Vierkotten J, Tory K, Golzio C, Lacoste T, Besse L, Ozilou C, Moutkine I, Hellman NE, Anselme I, Silbermann F, Vesque C. Gerhardt C, Rattenberry E, Wolf MT, Gubler MC, Martinovic J, Encha-Razavi F, Boddaert N, Gonzales M, Macher MA, Nivet H, Champion G, Bertheleme JP, Niaudet $\mathrm{P}$, McDonald F, Hildebrandt F, Johnson CA, Vekemans M, Antignac C, Ruther U, Schneider-Maunoury S, Attie-Bitach T, Saunier S. The ciliary gene RPGRIP1L is mutated in cerebello-oculo-renal syndrome (Joubert syndrome type B) and Meckel syndrome. Nat Genet 2007;39:875-81.

40. Smith UM, Consugar M, Tee LJ, McKee BM, Maina EN, Whelan S, Morgan NV, Goranson E, Gissen P, Lilliquist S, Aligianis IA, Ward CJ, Pasha S, Punyashthiti R, Malik Sharif S, Batman PA, Bennett CP, Woods CG, McKeown C, Bucourt M, Miller CA, Cox P, Algazali L, Trembath RC, Torres VE, Attie-Bitach T, Kelly DA, Maher ER, Gattone VH 2nd, Harris PC, Johnson CA. The transmembrane protein meckelin (MKS3) is mutated in Meckel-Gruber syndrome and the wpk rat. Nat Genet 2006;38:191-6.

41. Baala L, Romano S, Khaddour R, Saunier S, Smith UM, Audollent S, Ozilou C, Faivre L, Laurent N, Foliguet B, Munnich A, Lyonnet S, Salomon R, Encha-Razavi F, Gubler MC, Boddaert N, de Lonlay P, Johnson CA, Vekemans M, Antignac C, Attie-Bitach T. The Meckel-Gruber syndrome gene, MKS3, is mutated in Joubert syndrome. Am J Hum Genet 2007:80:186-94.

42. Khaddour R, Smith U, Baala L, Martinovic J, Clavering D, Shaffiq R, Ozilou C, Cullinane A, Kyttala M, Shalev S, Audollent S, d'Humieres C, Kadhom N, Esculpavit C, Viot G, Boone C, Oien C, Encha-Razavi F, Batman PA, Bennett CP, Woods CG, Roume J, Lyonnet S, Genin E, Le Merrer M, Munnich A, Gubler MC, Cox P, Macdonald F, Vekemans M, Johnson CA, Attie-Bitach T. Spectrum of MKS1 and MKS3 mutations in Meckel syndrome: a genotype-phenotype correlation. Mutation in brief \#960. Online. Hum Mutat 2007:28:523-4.

43. Consugar MB, Kubly VJ, Lager DJ, Hommerding CJ, Wong WC, Bakker E, Gattone VH 2nd, Torres VE, Breuning MH, Harris PC. Molecular diagnostics of Meckel-Gruber syndrome highlights phenotypic differences between MKS1 and MKS3. Hum Genet 2007;121:591-9.

44. Nachury MV, Loktev AV, Zhang Q, Westlake CJ, Peranen J, Merdes A, Slusarski DC, Scheller RH, Bazan JF, Sheffield VC, Jackson PK. A core complex of BBS proteins cooperates with the GTPase Rab8 to promote ciliary membrane biogenesis. Cell 2007:129:1201-13.

45. Frayling TM, Timpson NJ, Weedon MN, Zeggini E, Freathy RM, Lindgren CM, Perry JR, Elliott KS, Lango H, Rayner NW, Shields B, Harries LW, Barrett JC, Ellard S, Groves CJ, Knight B, Patch AM, Ness AR, Ebrahim S, Lawlor DA, Ring SM, BenShlomo Y, Jarvelin MR, Sovio U, Bennett AJ, Melzer D, Ferrucci L, Loos RJ, Barroso I. Wareham NJ, Karpe F, Owen KR, Cardon LR, Walker M, Hitman GA, Palmer CN, Doney AS, Morris AD, Smith GD, Hattersley AT, McCarthy MI. A common variant in the FTO gene is associated with body mass index and predisposes to childhood and adult obesity. Science 2007:316:889-94.

46. Dina C, Meyre D, Gallina S, Durand E, Korner A, Jacobson P, Carlsson LM, Kiess W, Vatin V, Lecoeur C, Delplanque J, Vaillant E, Pattou F, Ruiz J, Weill J, Levy-Marchal C, Horber F, Potoczna N, Hercberg S, Le Stunff C, Bougneres P, Kovacs P, Marre M, Balkau B, Cauchi S, Chevre JC, Froguel P. Variation in FTO contributes to childhood obesity and severe adult obesity. Nat Genet 2007;39:724-6.

47. Mollet G, Silbermann F, Delous M, Salomon R, Antignac C, Saunier S. Characterization of the nephrocystin/nephrocystin-4 complex and subcellular localization of nephrocystin-4 to primary cilia and centrosomes. Hum Mol Genet 2005;14:645-56.

48. Nurnberger J, Bacallao RL, Phillips CL. Inversin forms a complex with catenins and $\mathrm{N}$-cadherin in polarized epithelial cells. Mol Biol Cell 2002;13:3096-106.

49. Wolf MT, Lee J, Panther F, Otto EA, Guan KL, Hildebrandt F. Expression and phenotype analysis of the nephrocystin-1 and nephrocystin-4 homologs in Caenorhabditis elegans. J Am Soc Nephrol 2005;16:676-87.

50. Ou G, Koga M, Blacque OE, Murayama T, Ohshima Y, Schafer JC, Li C, Yoder BK, Leroux MR, Scholey JM. Sensory ciliogenesis in Caenorhabditis elegans: assignment of IFT components into distinct modules based on transport and phenotypic profiles. Mol Biol Cell 2007:18:1554-69.

51. Nurnberger J, Kribben A, Opazo Saez A, Heusch G, Philipp T, Phillips CL. The Invs gene encodes a microtubule-associated protein. J Am Soc Nephrol 2004;15:170010 .
52. Rundle DR, Gorbsky G, Tsiokas L. PKD2 interacts and co-localizes with mDia1 to mitotic spindles of dividing cells: role of mDia1 IN PKD2 localization to mitotic spindles. J Biol Chem 2004;279:29728-39.

53. Lin F, Hiesberger $T$, Cordes K, Sinclair AM, Goldstein LS, Somlo S, Igarashi $P$. Kidney-specific inactivation of the KIF3A subunit of kinesin-II inhibits renal ciliogenesis and produces polycystic kidney disease. Proc Natl Acad Sci U S A 2003;100:5286-91.

54. Signor D, Wedaman KP, Rose LS, Scholey JM. Two heteromeric kinesin complexes in chemosensory neurons and sensory cilia of Caenorhabditis elegans. Mol Biol Cell 1999:10:345-60.

55. Snow JJ, Ou G, Gunnarson AL, Walker MR, Zhou HM, Brust-Mascher I, Scholey JM. Two anterograde intraflagellar transport motors cooperate to build sensory cilia on C. elegans neurons. Nat Cell Biol 2004;6:1109-13.

56. Pan J, You Y, Huang T, Brody SL. RhoA-mediated apical actin enrichment is required for ciliogenesis and promoted by Foxi1. J Cell Sci 2007;120:1868-76.

57. Park TJ, Haigo SL, Wallingford JB. Ciliogenesis defects in embryos lacking inturned or fuzzy function are associated with failure of planar cell polarity and Hedgehog signaling. Nat Genet 2006;38:303-11.

58. Vladar EK, Stearns T. Molecular characterization of centriole assembly in ciliated epithelial cells. J Cell Biol 2007;178:31-42.

59. Jurczyk A, Gromley A, Redick S, San Agustin J, Witman G, Pazour GJ, Peters DJ, Doxsey S. Pericentrin forms a complex with intraflagellar transport proteins and polycystin-2 and is required for primary cilia assembly. J Cell Biol 2004:166:637-43.

60. Geng L, Okuhara D, Yu Z, Tian X, Cai Y, Shibazaki S, Somlo S. Polycystin-2 traffics to cilia independently of polycystin-1 by using an N-terminal RVxP motif. J Cell Sci 2006;119:1383-95.

61. Kim JC, Badano JL, Sibold S, Esmail MA, Hill J, Hoskins BE, Leitch CC, Venner K Ansley SJ, Ross AJ, Leroux MR, Katsanis N, Beales PL. The Bardet-Biedl protein BBS4 targets cargo to the pericentriolar region and is required for microtubule anchoring and cell cycle progression. Nat Genet 2004;36:462-70.

62. Kim JC, Ou YY, Badano JL, Esmail MA, Leitch CC, Fiedrich E, Beales PL, Archibald JM, Katsanis N., Rattner J.B, Leroux MR. MKKS/BBS6, a divergent chaperonin-like protein linked to the obesity disorder Bardet-Biedl syndrome, is a novel centrosomal component required for cytokinesis. J Cell Sci 2005;118:1007-20.

63. Arts HH, Doherty D, van Beersum SE, Parisi MA, Letteboer SJ, Gorden NT, Peters TA, Marker T, Voesenek K, Kartono A, Ozyurek H, Farin FM, Kroes HY, Wolfrum U, Brunner HG, Cremers FP, Glass IA, Knoers NV, Roepman R. Mutations in the gene encoding the basal body protein RPGRIP1L, a nephrocystin-4 interactor, cause Joubert syndrome. Nat Genet 2007;39:882-8

64. Roepman R, Letteboer SJ, Arts HH, van Beersum SE, Lu X, Krieger E, Ferreira PA, Cremers FP. Interaction of nephrocystin- 4 and RPGRIP1 is disrupted by nephronophthisis or Leber congenital amaurosis-associated mutations. Proc Natl Acad Sci U S A 2005;102:18520-5

65. Wu Y, Dai XQ, Li Q, Chen CX, Mai W, Hussain Z, Long W, Montalbetti N, Li G, Glynne R, Wang S, Cantiello HF, Wu G, Chen XZ. Kinesin-2 mediates physical and functional interactions between polycystin-2 and fibrocystin. Hum Mol Genet 2006:15:3280-92

66. Cole DG, Diener DR, Himelblau AL, Beech PL, Fuster JC, Rosenbaum JL. Chlamydomonas kinesin-II-dependent intraflagellar transport (IFT): IFT particles contain proteins required for ciliary assembly in Caenorhabditis elegans sensory neurons. J Cell Biol 1998;141:993-1008.

67. Fliegauf M, Horvath J, von Schnakenburg C, Olbrich H, Muller D, Thumfart J, Schermer B, Pazour GJ, Neumann HP, Zentgraf H, Benzing T, Omran H. Nephrocystin specifically localizes to the transition zone of renal and respiratory cilia and photoreceptor connecting cilia. J Am Soc Nephrol 2006;17:2424-33.

68. Schermer B, Hopker K, Omran H, Ghenoiu C, Fliegauf M, Fekete A, Horvath J, Kottgen M, Hackl M, Zschiedrich S, Huber TB, Kramer-Zucker A, Zentgraf H, Blaukat A, Walz G, Benzing T. Phosphorylation by casein kinase 2 induces PACS-1 binding of nephrocystin and targeting to cilia. Embo J 2005;24:4415-24.

69. Pazour GJ, Agrin N, Leszyk J, Witman GB. Proteomic analysis of a eukaryotic cilium. J Cell Biol 2005:170:103-13.

70. Dutcher SK. Flagellar assembly in two hundred and fifty easy-to-follow steps. Trends Genet 1995;11:398-404.

71. Cole DG. The intraflagellar transport machinery of Chlamydomonas reinhardtii. Traffic 2003; 4:435-42.

72. Moyer JH, Lee-Tischler MJ, Kwon HY, Schrick JJ, Avner ED, Sweeney WE, Godfrey VL, Cacheiro NL, Wilkinson JE, Woychik RP. Candidate gene associated with a mutation causing recessive polycystic kidney disease in mice. Science 1994:264:1329-33.

73. Onuchic LF, Schrick JJ, Ma J, Hudson T, Guay-Woodford LM, Zerres K, Woychik $\mathrm{RP}$, Reeders ST. Sequence analysis of the human hTg737 gene and its polymorphic sites in patients with autosomal recessive polycystic kidney disease. Mamm Genome 1995;6:805-8

74. Beales PL, Bland E, Tobin JL, Bacchelli C, Tuysuz B, Hill J, Rix S, Pearson CG, Kai M, Hartley J, Johnson C, Irving M, Elcioglu N, Winey M, Tada M, Scambler PJ. IFT80, which encodes a conserved intraflagellar transport protein, is mutated in Jeune asphyxiating thoracic dystrophy. Nat Genet 2007:39:727-9.

75. Hildebrandt $\mathbf{F}$, Otto E. Cilia and centrosomes: a unifying pathogenic concept for cystic kidney disease? Nat Rev Genet 2005;6:928-40.

76. Green JS, Parfrey PS, Harnett JD, Farid NR, Cramer BC, Johnson G, Heath 0 McManamon PJ, O'Leary E, Pryse-Phillips W. The cardinal manifestations of BardetBiedl syndrome, a form of Laurence-Moon-Biedl syndrome. N Engl J Med 1989:321:1002-9. 
77. Sheffield VC, Carmi R, Kwitek-Black A, Rokhlina T, Nishimura D, Duyk GM, Elbedour K, Sunden SL, Stone EM. Identification of a Bardet-Biedl syndrome locus on chromosome 3 and evaluation of an efficient approach to homozygosity mapping. Hum Mol Genet 1994:3:1331-5.

78. Katsanis N, Ansley SJ, Badano JL, Eichers ER, Lewis RA, Hoskins BE, Scambler PJ, Davidson WS, Beales PL, Lupski JR. Triallelic inheritance in Bardet-Biedl syndrome, a Mendelian recessive disorder. Science 2001;293:2256-9.

79. Badano JL, Kim JC, Hoskins BE, Lewis RA, Ansley SJ, Cutler DJ, Castellan C, Beales PL, Leroux MR, Katsanis N. Heterozygous mutations in BBS1, BBS2 and BBS6 have a potential epistatic effect on Bardet-Biedl patients with two mutations at a second BBS locus. Hum Mol Genet 2003;12:1651-9.

80. Stoetzel C, Laurier V, Davis EE, Muller J, Rix S, Badano JL, Leitch CC, Salem N, Chouery E, Corbani S, Jalk N, Vicaire S, Sarda P, Hamel C, Lacombe D, Holder M, Odent S, Holder S, Brooks AS, Elcioglu NH, Silva ED, Rossillion B, Sigaudy S, de Ravel TJ, Lewis RA, Leheup B, Verloes A, Amati-Bonneau P, Megarbane A, Poch O, Bonneau D, Beales PL, Mandel JL, Katsanis N, Dollfus H. BBS10 encodes a vertebrate-specific chaperonin-like protein and is a major BBS locus. Nat Genet 2006;38:521-4.

81. Badano JL, Leitch CC, Ansley SJ, May-Simera H, Lawson S, Lewis RA, Beales PL, Dietz HC, Fisher S, Katsanis N. Dissection of epistasis in oligogenic Bardet-Biedl syndrome. Nature 2006;439:326-30.

82. Blacque $\mathbf{O E}$, Reardon MJ, Li C, McCarthy J, Mahjoub MR, Ansley SJ, Badano JL, Mah AK, Beales PL, Davidson WS, Johnsen RC, Audeh M, Plasterk RH, Baillie DL, Katsanis N, Quarmby LM, Wicks SR, Leroux MR. Loss of C. elegans BBS-7 and BBS8 protein function results in cilia defects and compromised intraflagellar transport. Genes Dev 2004;18:1630-42.

83. Huangfu D, Liu A, Rakeman AS, Murcia NS, Niswander L, Anderson KV. Hedgehog signalling in the mouse requires intraflagellar transport proteins. Nature 2003:426:83-7.

84. Low SH, Vasanth S, Larson CH, Mukherjee S, Sharma N, Kinter MT, Kane ME, Obara T, Weimbs T. Polycystin-1, STAT6, and P100 function in a pathway that transduces ciliary mechanosensation and is activated in polycystic kidney disease. Dev Cell 2006;10:57-69.

85. Hiesberger T, Gourley E, Erickson A, Koulen P, Ward CJ, Masyuk TV, Larusso NF, Harris PC, Igarashi P. Proteolytic cleavage and nuclear translocation of fibrocystin and activation of protein kinase C. J Biol Chem 2006;281:34357-64.

86. Hanaoka K, Oian F, Boletta A, Bhunia AK, Piontek K, Tsiokas L, Sukhatme VP, Guggino WB, Germino GG. Co-assembly of polycystin-1 and -2 produces unique cation-permeable currents. Nature 2000;408:990-4.

87. Luo Y, Vassilev PM, Li X, Kawanabe Y, Zhou J. Native polycystin 2 functions as a plasma membrane Ca2+-permeable cation channel in renal epithelia. Mol Cell Biol 2003:23:2600-7.

88. Li X, Luo Y, Starremans PG, McNamara CA, Pei Y, Zhou J. Polycystin-1 and polycystin-2 regulate the cell cycle through the helix-loop-helix inhibitor Id2. Nat Cell Biol 2005; 7:1202-12.

89. Phillips CL, Miller KJ, Filson AJ, Nurnberger J, Clendenon JL, Cook GW, Dunn KW, Overbeek PA, Gattone VH 2nd, Bacallao RL. Renal cysts of inv/inv mice resemble early infantile nephronophthisis. J Am Soc Nephrol 2004;15:1744-55.

90. Jauregui AR, Barr MM. Functional characterization of the $\mathrm{C}$. elegans nephrocystins NPHP-1 and NPHP-4 and their role in cilia and male sensory behaviors. Exp Cell Res 2005; 305:333-42.

91. Broadhead R, Dawe HR, Farr H, Griffiths S, Hart SR, Portman N, Shaw MK, Ginger ML, Gaskell SJ, McKean PG, Gull K. Flagellar motility is required for the viability of the bloodstream trypanosome. Nature 2006;440:224-7.

92. Ostrowski LE, Blackburn K, Radde KM, Moyer MB, Schlatzer DM, Moseley A, Boucher RC. A proteomic analysis of human cilia: identification of novel components. Mol Cell Proteomics 2002;1:451-65.

93. Smith JC, Northey JG, Garg J, Pearlman RE, Siu KW. Robust method for proteome analysis by MS/MS using an entire translated genome: demonstration on the ciliome of Tetrahymena thermophila. J Proteome Res 2005;4:909-19.

94. Liu 0, Tan G, Levenkova N, Li T, Pugh EN Jr, Rux JJ, Speicher DW, Pierce EA. The proteome of the mouse photoreceptor sensory cilium complex. Mol Cell Proteomics 2007:6:1299-1317.

95. Otto EA, Schermer B, Obara T, O'Toole JF, Hiller KS, Mueller AM, Ruf RG, Hoefele J, Beekmann F, Landau D, Foreman JW, Goodship JA, Strachan T, Kispert A, Wolf MT, Gagnadoux MF, Nivet H, Antignac C, Walz G, Drummond IA, Benzing T, Hildebrandt F. Mutations in INVS encoding inversin cause nephronophthisis type 2, linking renal cystic disease to the function of primary cilia and left-right axis determination. Nat Genet 2003;34:413-20.

96. Simons M, Gloy J, Ganner A, Bullerkotte A, Bashkurov M, Kronig C, Schermer B, Benzing T, Cabello OA, Jenny A, Mlodzik M, Polok B, Driever W, Obara T, Walz G. Inversin, the gene product mutated in nephronophthisis type II, functions as a molecular switch between Wnt signaling pathways. Nat Genet 2005;37:537-43.
97. Morgan D, Goodship J, Essner JJ, Vogan KJ, Turnpenny L, Yost HJ, Tabin CJ, Strachan $T$. The left-right determinant inversin has highly conserved ankyrin repeat and IO domains and interacts with calmodulin. Hum Genet 2002;110:377-84.

98. Olbrich H, Fliegauf M, Hoefele J, Kispert A, Otto E, Volz A, Wolf MT, Sasmaz G, Trauer U, Reinhardt R, Sudbrak R, Antignac C, Gretz N, Walz G, Schermer B, Benzing T, Hildebrandt F, Omran H. Mutations in a novel gene, NPHP3, cause adolescent nephronophthisis, tapeto-retinal degeneration and hepatic fibrosis. Nat Genet 2003;34:455-9.

99. Roume J, Genin E, Cormier-Daire V, Ma HW, Mehaye B, Attie T, Razavi-Encha F, Fallet-Bianco C, Buenerd A, Clerget-Darpoux F, Munnich A, Le Merrer M. A gene for Meckel syndrome maps to chromosome 11q13. Am J Hum Genet 1998;63:1095101.

100. Vierkotten J, Dildrop R, Peters T, Wang B, Ruther U. Ftm is a novel basal body protein of cilia involved in Shh signalling. Development 2007;134:2569-77.

101. Dixon-salazar TJ, Silhavy JL, Marsh SE, Louie CM, Scott LC, Gururaj A, Al-Gazali L, Al-Tawari AA, Kayserili H, Sztriha L, Gleeson JG. Mutations in the AHI1 gene, encoding jouberin, cause Joubert Syndrome with cortical polymicrogyria. Am J Hum Genet 2004;75:979-87.

102. Mykytyn K, Braun T, Carmi R, Haider NB, Searby CC, Shastri M, Beck G, Wright AF lannaccone A, Elbedour K, Riise R, Baldi A, Raas-Rothschild A, Gorman SW, Duhl DM, Jacobson SG, Casavant T, Stone EM, Sheffield VC. Identification of the gene that, when mutated, causes the human obesity syndrome BBS4. Nat Genet 2001;28:188-91.

103. Nishimura DY, Searby CC, Carmi R, Elbedour K, Van Maldergem L, Fulton AB, Lam BL, Powell BR, Swiderski RE, Bugge KE, Haider NB, Kwitek-Black AE, Ying L, Duhl DM, Gorman SW, Heon E, lannaccone A, Bonneau D, Biesecker LG, Jacobson SG, Stone EM, Sheffield VC. Positional cloning of a novel gene on chromosome $16 q$ causing Bardet-Biedl syndrome (BBS2). Hum Mol Genet 2001;10:865-74.

104. Chiang AP, Nishimura D, Searby C, Elbedour K, Carmi R, Ferguson AL, Secrist J, Braun T, Casavant T, Stone EM, Sheffield VC. Comparative genomic analysis identifies an ADP-ribosylation factor-like gene as the cause of Bardet-Biedl syndrome (BBS3). Am J Hum Genet 2004;75:475-84.

105. Fan Y, Esmail MA, Ansley SJ, Blacque OE, Boroevich K, Ross AJ, Moore SJ, Badano JL, May-Simera H, Compton DS, Green JS, Lewis RA, van Haelst MM, Parfrey PS, Baillie DL, Beales PL, Katsanis N, Davidson WS, Leroux MR. Mutations in a member of the Ras superfamily of small GTP-binding proteins causes Bardet-Biedl syndrome. Nat Genet 2004;36:989-93.

106. Stone DL, Slavotinek A, Bouffard GG, Banerjee-Basu S, Baxevanis AD, Barr M, Biesecker LG. Mutation of a gene encoding a putative chaperonin causes McKusickKaufman syndrome. Nat Genet 2000:25:79-82.

107. Slavotinek AM, Stone EM, Mykytyn K, Heckenlively JR, Green JS, Heon E, Musarella MA, Parfrey PS, Sheffield VC, Biesecker LG. Mutations in MKKS cause Bardet-Biedl syndrome. Nat Genet 2000;26:15-16.

108. Katsanis N, Beales PL, Woods MO, Lewis RA, Green JS, Parfrey PS, Ansley SJ, Davidson WS, Lupski JR. Mutations in MKKS cause obesity, retinal dystrophy and renal malformations associated with Bardet-Biedl syndrome. Nat Genet 2000;26:67-70.

109. Ansley SJ, Badano JL, Blacque OE, Hill J, Hoskins BE, Leitch CC, Kim JC, Ross AJ, Eichers ER, Teslovich TM, Mah AK, Johnsen RC, Cavender JC, Lewis RA, Leroux MR, Beales PL, Katsanis N. Basal body dysfunction is a likely cause of pleiotropic Bardet-Biedl syndrome. Nature 2003;425:628-33.

110. Nishimura DY, Swiderski RE, Searby CC, Berg EM, Ferguson AL, Hennekam R, Merin S, Weleber RG, Biesecker LG, Stone EM, Sheffield VC. Comparative genomics and gene expression analysis identifies BBS9, a new Bardet-Biedl syndrome gene. Am J Hum Genet 2005; 77:1021-33.

111. Chiang AP, Beck JS, Yen HJ, Tayeh MK, Scheetz TE, Swiderski RE, Nishimura DY, Braun TA, Kim KY, Huang J, Elbedour K, Carmi R, Slusarski DC, Casavant TL, Stone EM, Sheffield VC. Homozygosity mapping with SNP arrays identifies TRIM32, an E3 ubiquitin ligase, as a Bardet-Biedl syndrome gene (BBS11). Proc Natl Acad Sci U S A 2006;103:6287-92.

112. Stoetzel C, Muller J, Laurier V, Davis EE, Zaghloul NA, Vicaire S, Jacquelin C, Plewniak F, Leitch CC, Sarda P, Hamel C, de Ravel TJ, Lewis RA, Friederich E, Thibault C, Danse JM, Verloes A, Bonneau D, Katsanis N, Poch O, Mandel JL, Dollfus $\mathrm{H}$. Identification of a novel BBS gene (BBS12) highlights the major role of a vertebrate-specific branch of chaperonin-related proteins in Bardet-Biedl syndrome. Am J Hum Genet 2007:80:1-11.

113. Ferrante MI, Zullo A, Barra A, Bimonte S, Messaddeq N, Studer M, Dolle P, Franco B Oral-facial-digital type I protein is required for primary cilia formation and left-right axis specification Nat Genet 2006;38:112-17.

114. Lucker BF, Behal RH, Qin H, Siron LC, Taggart WD, Rosenbaum JL, Cole DG. Characterization of the intraflagellar transport complex $\mathrm{B}$ core: direct interaction of the IFT81 and IFT74/72 subunits. J Biol Chem 2005;280:27688-96. 